\title{
Nonlinear deformation analysis for precast pre-stressed concrete beam systems
}

\author{
Thi Thuy Van Tran ${ }^{1, *}$ and David Shapiro ${ }^{2}$ \\ ${ }^{1}$ Civil Engineering Faculty, Hanoi Architectural University, Km. 10 Nguyen Trai, Thanh Xuan, \\ Hanoi, Viet Nam \\ ${ }^{2}$ Voronezh State Technical University, Russia
}

\begin{abstract}
The structural systems such as road bridge beam systems (span superstructure) or beam systems used in high-rise buildings with precast pre-stressed reinforced concrete might be subjected to the load higher than the calculated load of the design process. In the process of operation the internal forces of the beams reach to a certain value, the section stiffness in elements will be changed. The change in section stiffness will lead to redistribution of internal forces in the whole system. However, that has not been included in the design process. The paper presents nonlinear deformation analysis of precast pre-stressed beam system used in road bridge span superstructure or high-rise buildings using nonlinear model of materials according to Russian construction codes to build the relationship between internal forces and section stiffness. From the calculation results, some comments will be recommended about increased load capacity in comparison with the results obtained from analysis using linear model of material.
\end{abstract}

\section{Introduction}

Today, in Vietnam for reinforced concrete structures, the design based on the construction standard TCVN 5574-2012 [1] which recommends considering plastic deformation of concrete and reinforcement or linear elastic material assumption. However, in the standard, there are no specific calculation instructions in the case including plastic deformation of concrete and reinforcement. Therefore, most of the current designs are still calculated, under the assumption that the working materials in the elastic phase.

The precast pre-stressed beam structure is a structural type applied in road bridge beam system or beam systems used in high-rise buildings. The advantage of this structural type is that the construction process will be fast due to the high construction industrialization, meet the demand for certain construction progress and decrease product prices. In Vietnam, highrise buildings using precast construction technology and pre-stressed reinforced concrete beams are widely used to satisfy requirements of a part of low and middle-income residents in big cities such as Hanoi and Ho Chi Minh cities.

In the process of operation these systems sometimes have to be subjected the load higher than the original design load. In that case, it is necessary to have calculations to

\footnotetext{
* Corresponding author: ttthvan.hau@gmail.com
} 
explain as well as to make necessary recommendations about the reserve of load capacity of this structure. The nonlinear deformation analysis using nonlinear materials model according to the Russian codes allows building the relationship between internal force and section stiffness in each beam. Applying the results of this analysis to the precast prestressed reinforced concrete beam structure systems allows seeing the redistribution of internal force in the whole system. Consequently, conclusions can be made about the reserve of the load capacity of these of structure types under the condition that they are subjected to a load higher than the original design load.

Figure 1 shows example of cross-sections of the road bridge beam system.

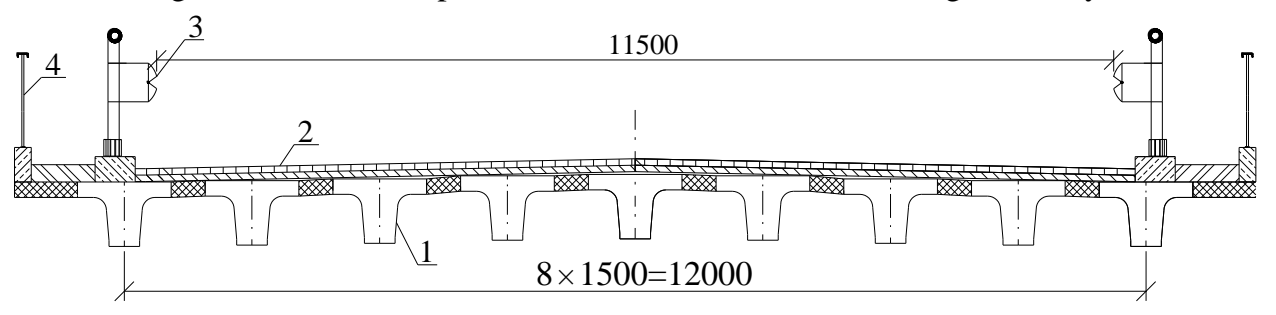

Fig.1. Example of cross section of road bridge span superstructure.

In order to design and evaluate the load capacity of precast pre-stressed reinforced concrete beams, it has been carried out to calculate according to the common limit state theory for determination the caculated values of internal forces $M_{c}$ and $Q_{c}$ (caculated bending moment and shear force) in beams under the effect of different types of loads. Then compare with the critical values of internal forces $\mathrm{M}_{\mathrm{cr}}$ and $\mathrm{Q}_{\mathrm{cr}}$ (critical bending moment and shear force) in the dangerous sections of the beams.

The calculation method according to the common limit state is often applied in the initial design calculation process. However, in order to assess the load bearing capacity of an operating structural system subjected to the load higher than the load used in the design process, or there are damaged beams in the system, this method has shown certain limitations. The limitations are due to the following reasons:

- At a certain section of a beam reaching the critical value of the bending moment (forming plastic hinge), which means that this beam can not be subjected to the load, but does not mean that the entire beam system has reached to the limit state.

When the internal forces in the beam increases to a certain value, the section stiffness in the beam gradually decreases, the stress - strain state of that beam changes. At this time the internal forces redistribute in the entire beam system. This will lead that the calculation results will differ from the case of caculation with the initial section stiffness of the beam.

From the above reasons, it can be observed that in order to re-evaluate the load capacity of the beam system in operation, other criteria and views need to be added to the limit state theory. This paper presents a calculation method that can explain higher load bearing capacity during operation process. This calculation method includes the following main steps:

Nonlinear deformation analysis for each beams using nonlinear material models of Russian codes SP 52-101-2003 [2], SP 52-102-2004 [3];

Using the results of the nonlinear deformation analysis for each beam, in particular, using the diagram of the section stiffness depending on the internal forces appearing in each beam into the overall of beam system using structural analysis software of the FEM method. In this step, consider that the load (here is the live load) gradually increases. 


\section{Nonlinear deformation analysis}

\subsection{Theory background}

The nonlinear deformation analysis using nonlinear material model according to the Russian codes SP 52 - 101 - 2003 [2]; SP 52 - 102 - 2004 [3] and the following assumptions:

The strains of compressive concrete, compressive and tensile reinforcement are linear corresponding to the flat cross section. Not to mention the work of tensile zone concrete.

The stress - strain relation of compressive concrete according to the 3-phase diagram (Figure 2a) of Russian Construction Code: SP 52 - 101 - 2003; SP 52 - 102 - 2004; The stress - strain relation of pre-stressed steel according to the 3-phase diagram (Figure 2b) of Russian Construction Code: SP 52 - 101 - 2003, in which $\varepsilon_{\mathrm{p} 1}=0,9 \mathrm{R}_{\mathrm{p}} / \mathrm{E}_{\mathrm{p}}, \varepsilon_{\mathrm{p} 0}=\mathrm{R}_{\mathrm{p}} / \mathrm{E}_{\mathrm{p}}+0,002$, $\varepsilon_{\mathrm{p} 0}^{\prime}=1,1 \mathrm{R}_{\mathrm{p}} / \mathrm{E}_{\mathrm{p}}+0,004, \varepsilon_{\mathrm{p} 2}=0,015, \sigma_{\mathrm{p} 1}=0,9 \mathrm{R}_{\mathrm{p}}, \sigma_{\mathrm{p} 0}=\mathrm{R}_{\mathrm{p}}, \sigma_{\mathrm{p} 2}=1,1 \mathrm{R}_{\mathrm{p}}$;

Not to mention the creep and shrinkage of concrete;

The nonlinear deformation analysis is actually calculated by the strength, including the stress - strain state before the structure is destroyed. Solving the problem is to determine the strains $\varepsilon_{\mathrm{b}}, \varepsilon_{\mathrm{p}}$, and stresses $\sigma_{\mathrm{b}}, \sigma_{\mathrm{p}}$ in concrete and pre-stressed reinforcement by each point in the section height of the beam and curvature $1 / \rho$ ( $\rho$ - curvature radius) and section stiffness $\mathrm{M} /(1 / \rho)$ when increasing the bending moment from the value of bending moment subject to the static load to the value of the limit load.

a)

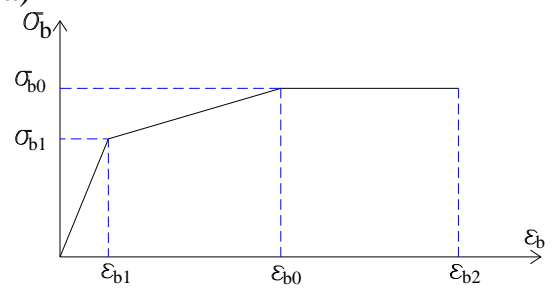

b)

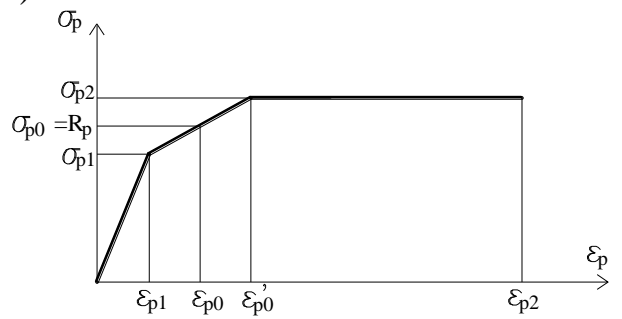

Fig. 2. Nonlinear material models: a - Compressive concrete, $b$ - pre-stressed steel.

The problem of stresses and strains distribution in cross section of bending reinforced concrete beams is inverse problem with the design calculation process: the independent variable is the strain of the compressive concrete $\varepsilon_{\mathrm{b}, \mathrm{z}=\mathrm{x}}$. Corresponding to the assumption of flat section the strains at points by the height of the section in the compressive concrete area $\varepsilon_{\mathrm{b}}$, in prestressed reinforcement $\varepsilon_{\mathrm{p}}$ are linear distributions. This allows to build the set of lines (with $\mathrm{z}$ being the coordinates of the sectional height from the neutral line of the section), for each such line can be determined the following parameters: strains which distributes at points by the section height $\varepsilon_{\mathrm{b}}, \varepsilon_{\mathrm{p}}$ and stresses $\sigma_{\mathrm{b}}, \sigma_{\mathrm{p}}$ (according to the diagram as shown in Figure 3 ) and the value of the internal forces in the compressive concrete area and in pre-stressed reinforcement respectively $F_{b}=\int_{A} \sigma_{b} d A, \quad \mathrm{~F}_{\mathrm{p}}=\sigma_{\mathrm{p}} \cdot \mathrm{A}_{\mathrm{p}}$, where $\mathrm{A}, \mathrm{dA}$

are areas of compressive zone of concrete and separated element; $A_{p}$ is the cross sectional area of pre-stressed reinforcement, $\sigma_{\mathrm{p}}$ is stress in pre-stressed reinforcement respectively with strain $\varepsilon_{\mathrm{p}}=\sigma_{\mathrm{pn}} / \mathrm{E}_{\mathrm{p}}+\varepsilon_{\mathrm{b}, \mathrm{z}=\mathrm{x}}\left(\mathrm{x}-\mathrm{h}_{0}\right) / \mathrm{x} ; \sigma_{\mathrm{pn}}$ is stress of extensive period of reinforcement (taking into account the stress loss); $\mathrm{h}_{0}=\mathrm{h}-\mathrm{a}_{\mathrm{p}}$ is caculated height of section, ap is distance from pre-stressed reinfocement center to lower edge of section; $x$ - height of compressive zone. Figure 3 shows all above mentioned dimensions.

From the set of straight lines with equation $\varepsilon=f(z)$, the real straight line (caculated line) is the line which satisfies the condition of all forces: $F=F_{b}+F_{p}=0$. 
From the above analysis, it is allowed to build diagrams or table, in which corresponding to each value $\varepsilon_{\mathrm{b}, \mathrm{z}=\mathrm{x}}$ can be had only one $\mathrm{v}$, alues $\mathrm{M}$ (bending moment) and $\mathrm{x}$ (height of compressive zone of section). Analyzing the relationship between 3 parameters $\varepsilon_{\mathrm{b}, \mathrm{z}=\mathrm{x}}, \mathrm{M}, \mathrm{x}$ to determine the strains $\varepsilon_{\mathrm{b}, \mathrm{z}} \varepsilon_{\mathrm{p}}$, the stresses $\sigma_{\mathrm{b}}, \sigma_{\mathrm{p}}$ in points by section height, bending curvature $1 / \rho=\left(\varepsilon_{\mathrm{p}}-\varepsilon_{\mathrm{b}, \mathrm{z}=\mathrm{x}}\right) / \mathrm{h}_{0}$ and bending stiffness $\mathrm{M} /(1 / \rho)=\mathrm{f}(\mathrm{M})$.

The bending stiffness of pre-stressed beams is considered as ratio $M /(1 / \rho)$, changing the determination in two deformation stages. In the first stage when the entire height of the section in compression, the equivalent area Ared and equivalent moment of inertia are determined for the entire section and are constant at this stage. In the second stage (when $\mathrm{x}<\mathrm{h}$ ) the bending stiffness is considered as ratio $\mathrm{M} /(1 / \rho)$ (where $\left.1 / \rho=\left|\varepsilon_{\mathrm{b}, \mathrm{z}=\mathrm{x}}\right| / \mathrm{x}=\left(\varepsilon_{\mathrm{p}}-\varepsilon_{\mathrm{b}, \mathrm{z}=\mathrm{x}}\right) / \mathrm{h}_{0}\right)$ defining like the case of reinforce concrete $[4,6,8]$

a)

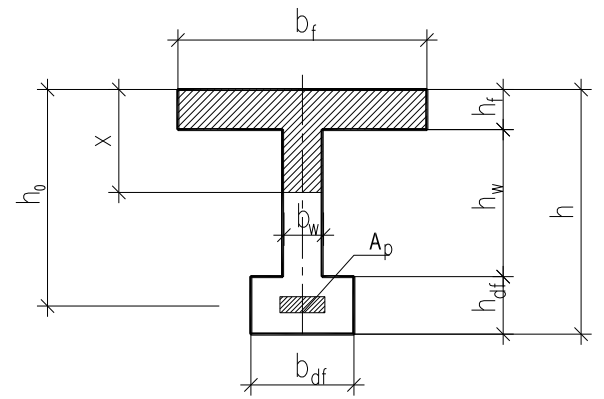

b)

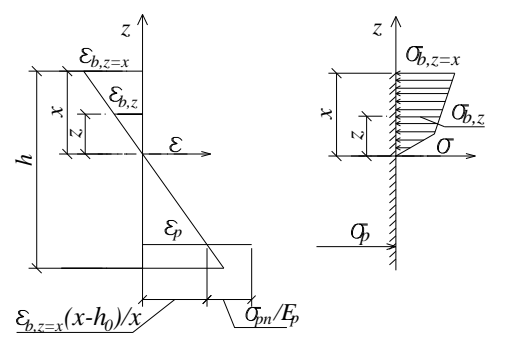

Fig. 3. Graph of nonlinear deformation analysis: a - cross section of precast pre-stressed beams; b graph of strains and stresses distribution by the section height of beam .

Thus, it is necessary to pay attention to specific characteristics of pre-stressed beams. When determining the bending curvature $1 / \rho$ and the sectional bending stiffness in second phase of the deformation process, the following two bending moments must be taken into account bending moment $M_{e x}$ (arising due to external force) and bending moment $M_{N}$ due to compression eccentric stress. But when building the relationship diagram $M /(1 / \rho)=f(M)$ bending moment $\mathrm{M}$ in the ratio $\mathrm{M} /(1 / \rho)$ is determined as algebraic sum of these moments and symbolized $\mathrm{M}_{\Sigma}$.

During the calculation process, it is noted that:

- Determine the geometric characteristics of the equivalent compressive concrete and reinforcement area corresponding to the strain of concrete at the edge of section $\varepsilon_{\mathrm{b}, \mathrm{z}=\mathrm{x}}$ and strain in the pre-stressed reinforcement $\varepsilon_{\mathrm{p}}=\sigma_{\mathrm{pn}} / \mathrm{E}_{\mathrm{p}}+\varepsilon_{\mathrm{b}, \mathrm{z}=\mathrm{x}}\left(\mathrm{x}-\mathrm{h}_{0}\right) /$. Where the height of compressive zone $\mathrm{x}$, equivalent area $\mathrm{A}_{\mathrm{red}}$ and first moment of area for neutral axix $\mathrm{S}_{\mathrm{red}, 0-0}$ according to the following formulas:

$$
\begin{gathered}
\mathrm{A}_{\mathrm{red}}=\Sigma \int\left[\left(\sigma_{\mathrm{b}} / \varepsilon_{\mathrm{b}} \mathrm{E}_{\mathrm{b}}\right) \mathrm{dA}\right]+\left(\sigma_{\mathrm{p}} / \varepsilon_{\mathrm{p}} \mathrm{E}_{\mathrm{b}}\right) \mathrm{A}_{\mathrm{p}}, \\
\mathrm{S}_{\mathrm{red}, 0-0}=\Sigma \int\left[\left(\sigma_{\mathrm{b}} / \varepsilon_{\mathrm{b}} \mathrm{E}_{\mathrm{b}}\right) \mathrm{z} \mathrm{dA}\right]-\left[\left(\sigma_{\mathrm{p}} / \varepsilon_{\mathrm{p}} \mathrm{E}_{\mathrm{b}}\right)\left(\mathrm{h}_{0}-\mathrm{x}\right)\right] \mathrm{A}_{\mathrm{p}},
\end{gathered}
$$

- Determine the position of center of the working section from the neutral axis $(\mathrm{t}-$ distance from the neutral axis to the center of the working section):

$$
\mathrm{t}=\mathrm{S}_{\text {red,0-0}} / \mathrm{A}_{\text {red }} \text {. }
$$

- Determine the strain of concrete at point of center of the working section:

$$
\varepsilon_{\mathrm{bC}}=\varepsilon_{\mathrm{b}, \mathrm{z}=\mathrm{x}}(\mathrm{t} / \mathrm{x}) \text {. }
$$

- Determine the eccentric compressive force $F_{N}$ at the value of strain and determine bending moment $\mathrm{M}_{\mathrm{N}}$ of this force at the center of the section

$$
\mathrm{F}_{\mathrm{N}}=\varepsilon_{\mathrm{bC}} \mathrm{E}_{\mathrm{b}} \mathrm{A}_{\mathrm{red}}=\varepsilon_{\mathrm{b}, \mathrm{z}=\mathrm{x}}(\mathrm{t} / \mathrm{x}) \mathrm{E}_{\mathrm{b}} \mathrm{A}_{\mathrm{red}},
$$




$$
\mathrm{M}_{\mathrm{N}}=\mathrm{F}_{\mathrm{N}}\left(\mathrm{h}_{0}-\mathrm{x}+\mathrm{t}\right)=\varepsilon_{\mathrm{b}, \mathrm{z}=\mathrm{x}}(\mathrm{t} / \mathrm{x}) \mathrm{E}_{\mathrm{b}} \mathrm{A}_{\text {red }}\left(\mathrm{h}_{0}-\mathrm{x}+\mathrm{t}\right)
$$

- The algebraic sum of bending moment $M \Sigma$ is determined by following formula:

$$
\mathrm{M}_{\Sigma}=\mathrm{M}_{\mathrm{ex}}+\mathrm{M}_{\mathrm{N}}=\mathrm{M}_{\mathrm{ex}}-\left|\varepsilon_{\mathrm{b}, \mathrm{z}=\mathrm{x}}(\mathrm{t} / \mathrm{x}) \mathrm{E}_{\mathrm{b}} \mathrm{A}_{\mathrm{red}}\left(\mathrm{h}_{0}-\mathrm{x}+\mathrm{t}\right)\right| .
$$

\subsection{Establishment of nonlinear deformation analysis procedure}

Step 1: Given input parameters of the problem: geometry dimensions of the section $\left(b, b_{f}, h, h_{f}\right)$, parameters of reinforcement $\left(A_{p}, a_{p}, h_{0}\right)$, material characteristics $\left(E_{b}, E_{p}, R_{b}\right.$, $\mathrm{R}_{\mathrm{p}}$ ), tensile stress in pre-stressed reinforcement $\sigma_{\mathrm{pn}}$

Step 2: Determine the geometrical characteristics of the section (equivalent section area, first moment of area $S_{\text {red }}$, distance from cross sectional center to upper and bottom edges $\mathrm{y}_{\mathrm{t}}, \mathrm{y}_{\mathrm{d}}$, moment of inertia $\mathrm{I}_{\text {red }}$, section modulus $\mathrm{W}_{\text {red }}^{\mathrm{t}}, \mathrm{W}_{\text {red }}^{\mathrm{d}}$;

Step 3: Establishment of the force balance equation to determint the height of the compressive zone of concrete $\mathrm{x}$ :

- Determine bending moment of external load corresponding to initial section stiffness:

$$
\mathrm{M}=\mathrm{W}_{\mathrm{red}}^{\mathrm{d}} \cdot\left[\left(\frac{\sigma_{\mathrm{pn}} \mathrm{A}_{\mathrm{p}}}{\mathrm{A}_{\mathrm{red}}}\right)+\left(\frac{\sigma_{\mathrm{pn}} \mathrm{A}_{\mathrm{p}} \cdot\left(\mathrm{y}_{\mathrm{d}}-\mathrm{a}_{\mathrm{p}}\right)}{\mathrm{W}_{\mathrm{red}}^{\mathrm{d}}}\right)\right]
$$

- Determine stress $\sigma_{\mathrm{b} 0}$ and strain $\varepsilon_{\mathrm{b} 0}$ of concrete at the upper edge of the section corresponding to determined bending moment $\mathrm{M}$

$$
\sigma_{\mathrm{b} 0}=\frac{-\mathrm{M}+\sigma_{\mathrm{pk}} \mathrm{A}_{\mathrm{p}}\left(\mathrm{y}_{\mathrm{d}}-\mathrm{a}_{\mathrm{p}}\right)}{\mathrm{W}_{\mathrm{red}}^{\mathrm{t}}}-\frac{\sigma_{\mathrm{pk}} \mathrm{A}_{\mathrm{p}}}{\mathrm{A}_{\mathrm{red}}}
$$

Here, check the condition: $\left|\sigma_{b 0}\right| \leq 0,6 R_{b}$ :

+ If $\left|\sigma_{b 0}\right| \leq 0,6 R_{b}$ then $\quad \mathrm{M}_{\text {init }}=\mathrm{M}$

$$
+ \text { If }\left|\sigma_{b 0}\right|>0,6 R_{b} \text { then } \quad \mathrm{M}_{\text {init }}=\mathrm{W}_{\text {red }}^{\mathrm{t}} \cdot\left[0.6 \mathrm{R}_{\mathrm{b}}+\frac{\sigma_{\mathrm{pn}} \mathrm{A}_{\mathrm{p}}\left(\mathrm{y}_{\mathrm{t}}-\mathrm{a}_{\mathrm{p}}\right)}{\mathrm{W}_{\text {red }}^{\mathrm{t}}}-\frac{\sigma_{\mathrm{pn}} \mathrm{A}_{\mathrm{p}}}{\mathrm{A}_{\text {red }}}\right]
$$

- $\quad$ Determine stresses in concrete and the forces in concrete and pre-stressed reinforcement when the section stiffness changes:

+ The strain in compressive concrete, pre-stressed reinforcement

$$
\varepsilon_{\mathrm{b}, \mathrm{z}}=\varepsilon_{\mathrm{b}, \mathrm{z}=\mathrm{x}}\left(\frac{\mathrm{z}}{\mathrm{x}}\right) ; \varepsilon_{\mathrm{p}}=\varepsilon_{\mathrm{b}, \mathrm{z}=\mathrm{x}}\left(\frac{\mathrm{x}-\mathrm{h}_{0}}{\mathrm{x}}\right)+\frac{\sigma_{\mathrm{pn}}}{\mathrm{E}}
$$

+ The formulas of the forces of concrete and pre-stressed reinforcement:

$$
\begin{aligned}
& \text { If } \mathrm{x} \leq \mathrm{h}_{\mathrm{f}}: \mathrm{F}_{\mathrm{b}}\left(\varepsilon_{\mathrm{b}}, \mathrm{x}\right)=\mathrm{b}_{\mathrm{f}} \int_{0}^{\mathrm{x}} \sigma_{\mathrm{b}}\left(\varepsilon_{\mathrm{b}, \mathrm{z}}\right) \mathrm{dz} \\
& \text { If } \mathrm{h}_{\mathrm{f}} \leq \mathrm{x} \leq \mathrm{h}_{\mathrm{f}}+\mathrm{h}_{\mathrm{w}}: \mathrm{F}_{\mathrm{b}}\left(\varepsilon_{\mathrm{b}}, \mathrm{x}\right)=\mathrm{b}_{\mathrm{w}} \int_{0}^{\mathrm{x}-\mathrm{h}_{\mathrm{f}}} \sigma_{\mathrm{b}}\left(\varepsilon_{\mathrm{b}, \mathrm{z}}\right) \mathrm{dz}+\mathrm{b}_{\mathrm{f}} \int_{\mathrm{x}-\mathrm{h}_{\mathrm{f}}}^{\mathrm{x}} \sigma_{\mathrm{b}}\left(\varepsilon_{\mathrm{b}, \mathrm{z}}\right) \mathrm{dz}
\end{aligned}
$$

If $\mathrm{h}_{\mathrm{f}}+\mathrm{h}_{\mathrm{w}} \leq \mathrm{x} \leq \mathrm{h}$ :

$$
\begin{gathered}
F_{b}\left(\varepsilon_{b}, x\right)=b_{d f} \int_{0}^{x-h_{w}-h_{f}} \sigma_{b}\left(\varepsilon_{b, z}\right) d z+b_{w} \int_{x-h_{w}-h_{f}}^{x-h_{f}} \sigma_{b}\left(\varepsilon_{b, z}\right) d z+b_{f} \int_{x-h_{f}}^{x} \sigma_{b}\left(\varepsilon_{b, z}\right) d z \\
F_{p}\left(\varepsilon_{b}, x\right)=\sigma_{p}\left(\varepsilon_{p}\right) A_{p}
\end{gathered}
$$

+ Determine the height of compressive zone of concrete by equation: 


$$
\mathrm{F}=\mathrm{F}_{\mathrm{b}}\left(\varepsilon_{\mathrm{b}}, \mathrm{x}\right)+\mathrm{F}_{\mathrm{p}}=0
$$

Step 4: Determine bending moment of the forces $F$ at neutral axis of the section

$$
\begin{aligned}
\text { If } x \leq h_{f}: \quad M_{b}\left(\varepsilon_{b}, x\right)=\left|b_{f} \int_{0}^{x} \sigma_{b}\left(\varepsilon_{b, z}\right) d z\right| & \\
\text { If } h_{f} \leq x \leq h_{f}+h_{w}: & M_{b}\left(\varepsilon_{b}, x\right)=\left|b_{w} \int_{0}^{x-h_{f}} \sigma_{b}\left(\varepsilon_{b, z}\right) \cdot z \cdot d z+b_{f} \int_{x-h_{f}}^{x} \sigma_{b}\left(\varepsilon_{b, z}\right) \cdot z \cdot d z\right|
\end{aligned}
$$

If: $h_{f}+h_{w} \leq x \leq h:$

$$
\begin{gathered}
M_{b}\left(\varepsilon_{b}, x\right)=\left|b_{d f} \int_{0}^{x-h_{w}-h_{f}} \sigma_{b}\left(\varepsilon_{b, z}\right) z \cdot d z+b_{w} \int_{x-h_{w}-h_{f}}^{x-h_{f}} \sigma_{b}\left(\varepsilon_{b, z}\right) \cdot z \cdot d z+b_{f} \int_{x-h_{f}}^{x} \sigma_{b}\left(\varepsilon_{b, z}\right) z \cdot d z\right| \\
M_{e x}=M_{b}\left(\varepsilon_{b}, x\right)+\left|F_{b}\left(\varepsilon_{b}, x\right)\right| \cdot\left(h_{0}-x\right) ;
\end{gathered}
$$

Step 5: Determine algebraic sum of bending moment $M_{\Sigma}$ of forces in compressive concrete and eccentric compressive force by formula (7):

Step 6: Determine bending curvature of separated element of beam with length $\mathrm{dl}$ :

$$
\frac{1}{\rho\left(\varepsilon_{\mathrm{b}, \mathrm{z}=\mathrm{x}}, \mathrm{x}\right)}=\left|\frac{\varepsilon_{\mathrm{b}, \mathrm{z}=\mathrm{x}}}{\mathrm{x}}\right|=\frac{\varepsilon_{\mathrm{p}}-\varepsilon_{\mathrm{b}, \mathrm{z}=\mathrm{x}}}{\mathrm{h}_{0}}
$$

Step 7: Determine section stiffness of separated elememt of beam with length dl:

$$
\mathrm{B}\left(\varepsilon_{\mathrm{b}, \mathrm{z}=\mathrm{x}}, \mathrm{x}\right)=\frac{\mathrm{M}_{\Sigma}}{1 / \rho\left(\varepsilon_{\mathrm{b}, \mathrm{z}=\mathrm{x}}, \mathrm{x}\right)}
$$

Step 8: Draw diagrams of relationships between above determined parameters.

Based on the proposed above mentioned method of nonlinear deformation analysis of pre-stressed beam the block diagram of algorithm is established (Figure 4) using MathCad caculation software.

\section{Example of nonlinear deformation analysis of pre-stressed beams}

The authors used the above established method for nonlinear deformation analysis of prestressed beam with any parameters of geometry section, length of beam and materials.

\subsection{Example 1}

Nonlinear deformation analysis of pre-stressed road bridge beam with following parameters: length of beam $12 \mathrm{~m}$ (caculated length $11.4 \mathrm{~m}$ ) and other parameters given in table 1 and Figure 5.

Material characteristics: Elastic modulus of concrete (Class B35) $\mathrm{E}_{\mathrm{b}}=31050 \mathrm{MPa}$, prestressed reinforcement (type $\mathrm{B}-\mathrm{II}$ ) $\mathrm{E}_{\mathrm{s}}=177000 \mathrm{Mpa}$; compression strength of concrete $\mathrm{R}_{\mathrm{b}}=17.5 \mathrm{MPa}$, reinforcement $\mathrm{R}_{\mathrm{p}}=1055 \mathrm{Mpa}, \sigma_{\mathrm{pn}}=878 \mathrm{MPa}$, in the middle section of beam $\mathrm{M}_{\text {init }}=684 \mathrm{kNm}, \quad \varepsilon_{b 0}=-1,69 \cdot 10^{-4}, \sigma_{b 0}=-5,24 \mathrm{MPa}$ 


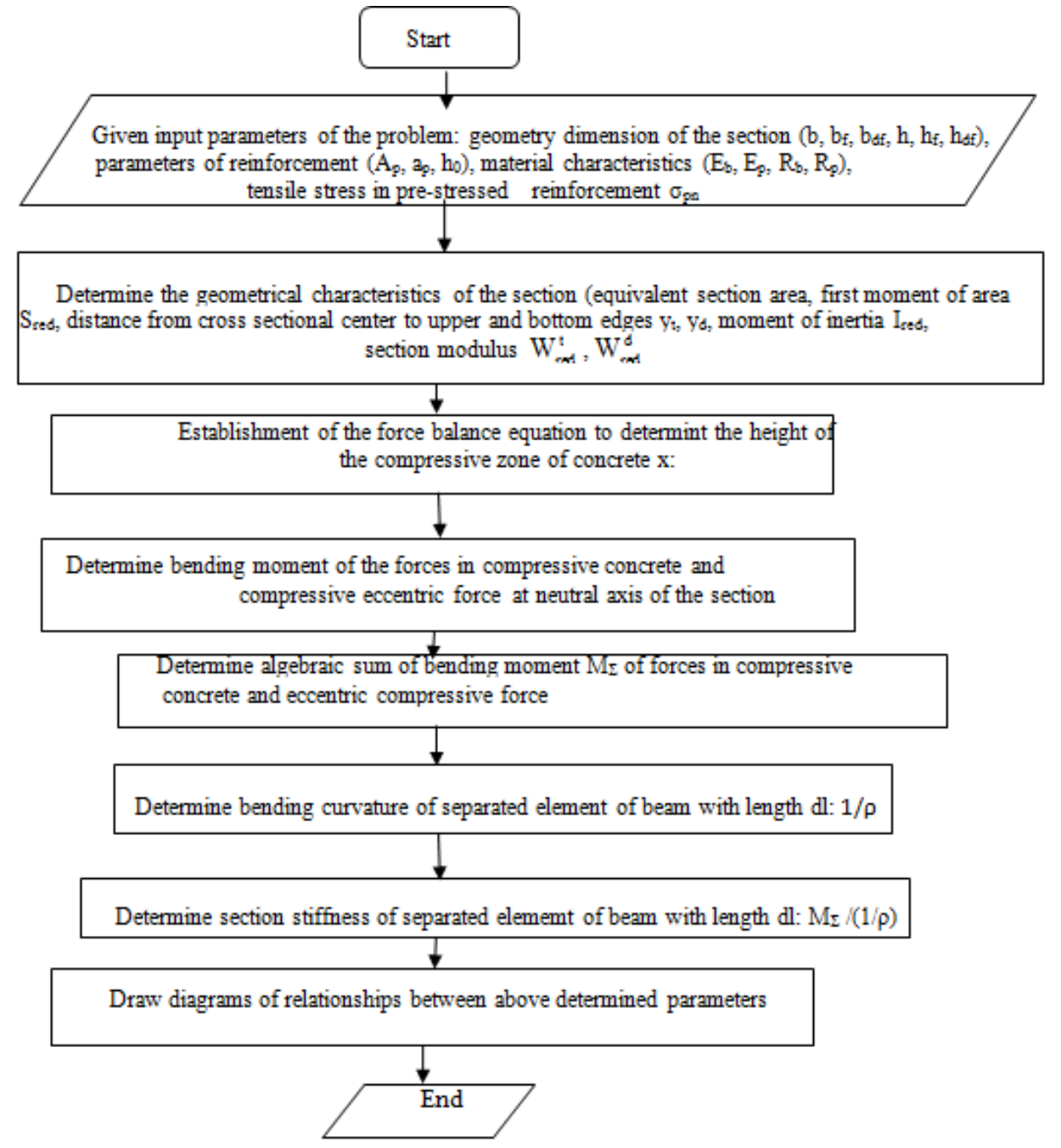

Fig. 4. Block diagram of algorithm for nonlinear deformation analysis of pre-stressed reinforced concrete beam .

Table 1. Input parameters and geometrical characteristics of beam section.

\begin{tabular}{|c|c|c|c|c|c|c|c|c|c|c|c|c|}
\hline $\begin{array}{l}\text { Section } \\
\qquad a, \mathrm{M}\end{array}$ & $\begin{array}{l}b, \\
\mathrm{~cm}\end{array}$ & $\begin{array}{l}B_{f}, \\
\mathrm{~cm}\end{array}$ & $\begin{array}{l}h, \\
\mathrm{~cm}\end{array}$ & $\begin{array}{l}h_{f}, \\
\mathrm{~cm}\end{array}$ & $\begin{array}{l}A_{p}, \\
\mathrm{~cm}^{2}\end{array}$ & $\begin{array}{l}a_{p}, \\
\mathrm{~cm}\end{array}$ & $\begin{array}{l}h_{0}, \\
\mathrm{~cm}\end{array}$ & $\begin{array}{l}A_{\text {red }}, \\
\mathrm{cm}^{2}\end{array}$ & $\begin{array}{l}Y_{n}, \\
\mathrm{~cm}\end{array}$ & $\begin{array}{c}I_{r e d} \\
10^{5} \mathrm{~cm}^{4}\end{array}$ & $\begin{array}{c}W_{r e d}^{n}, \\
10^{5} \\
\mathrm{~cm}^{3}\end{array}$ & $\begin{array}{c}W_{r e d}^{t}, \\
10^{5} \\
\mathrm{~cm}^{3}\end{array}$ \\
\hline 5,7 & 36 & 150 & 75 & 18 & 18,85 & 18 & 57 & 4859 & 48,77 & 22,91 & 0,4697 & 0,8736 \\
\hline 2,64 & 36 & 150 & 75 & 18 & 14,14 & 20,7 & 54,3 & 4833 & 49,04 & 22,82 & 0,4650 & 0,8792 \\
\hline 1,25 & 36 & 150 & 75 & 18 & 9,42 & 26 & 49 & 4806 & 49,30 & 22,74 & 0,4613 & 0,8850 \\
\hline 0,22 & 36 & 150 & 75 & 18 & 4,71 & 26 & 49 & 4779 & 49,55 & 22,71 & 0,4583 & 0,8924 \\
\hline
\end{tabular}




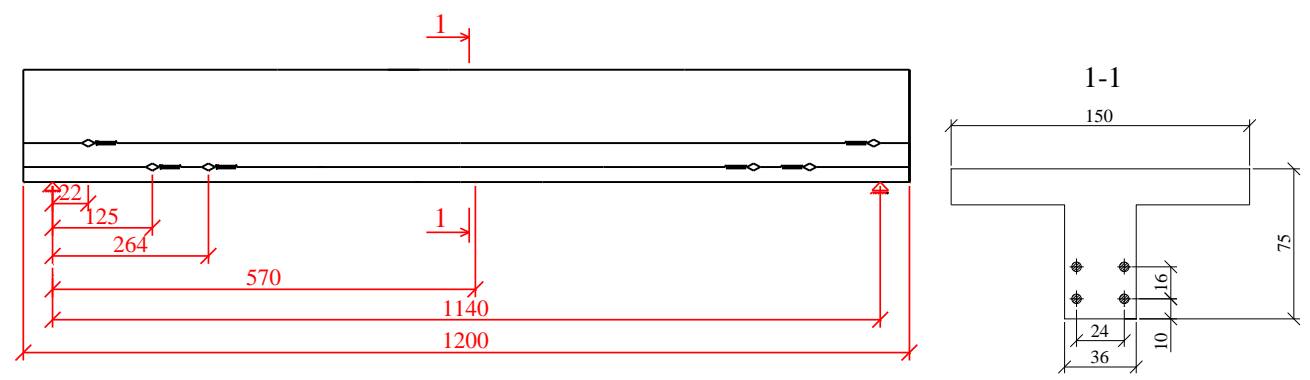

Fig. 5. Diagram of steel distribution along length and at the middle section of the pre-stressed road bridge beam.

The caculation is conducted using programme software MathCad and obtained the results, which illustrated relationships between parameters $M=f_{1}\left(\varepsilon_{b, z=x}\right), M /(1 / \rho)=f_{2}\left(\varepsilon_{b, z=x}\right)$, $M /(1 / \rho)=f_{3}(M)$ and shown in the Figure $6 a, b, c, d$ for the middle section of the pre-stressed road bridge beam with length $12 \mathrm{~m}$.

Table 2. Results of nonlinear deformation analysis for pre-stressed beam $12 \mathrm{~m}$ at middle section.

\begin{tabular}{|c|c|c|c|c|c|c|c|}
\hline $\begin{array}{l}\varepsilon_{b} \times \\
10^{4}\end{array}$ & $\begin{array}{l}x, \\
\mathrm{~cm}\end{array}$ & $\begin{array}{l}\varepsilon_{p} \times \\
10^{4}\end{array}$ & $\begin{array}{c}\text { Diagram } \\
\sigma_{b,}, \sigma_{p}(\mathrm{MPa})\end{array}$ & $\begin{array}{l}F_{p}, \\
\mathrm{kN}\end{array}$ & $\begin{array}{c}M / M_{\Sigma}, \\
\mathrm{kNm}\end{array}$ & $\begin{array}{l}1 / \rho \times \\
10^{4} \\
\mathrm{~m}^{-1}\end{array}$ & $\begin{array}{r}\mathrm{M}_{\Sigma} /(1 / \rho) \\
\mathrm{mNm}^{2}\end{array}$ \\
\hline$-1,69$ & 75 & 49 & 目的 & 1642 & $\frac{682,8}{1817}$ & 2,28 & 791,5 \\
\hline-4 & 20 & 57 & 두 $=963$ & 1815 & $\frac{913,1}{187,1}$ & 20 & 93,9 \\
\hline-8 & 15 & 73 & $\alpha=1028$ & 1937 & $\frac{993,6}{379,6}$ & 55 & 69,3 \\
\hline-12 & 13 & 89 & $a=1093$ & 2060 & $\frac{10625}{528,0}$ & 90 & 58,5 \\
\hline-16 & 12,7 & 105 & 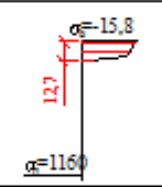 & 2187 & $\frac{1131,2}{652,8}$ & 126 & 51,6 \\
\hline
\end{tabular}

The last diagram $M /(1 / \rho)=f(M)$ is applied in to the second problem (spatial problem) of road bridge beam system to reflect the change of section stiffness along the length of the beam when the load increases gradually until forming plastic hinge at the certain section of the beam. And this lead to the redistribution of internal forces in the system, allows the 
entire system continue to subject to load despite of that the bending moment reached the limit value in a beam or some beam of the system.

a)

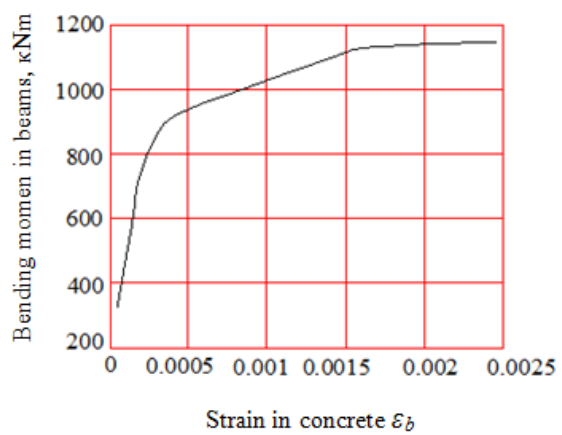

c)

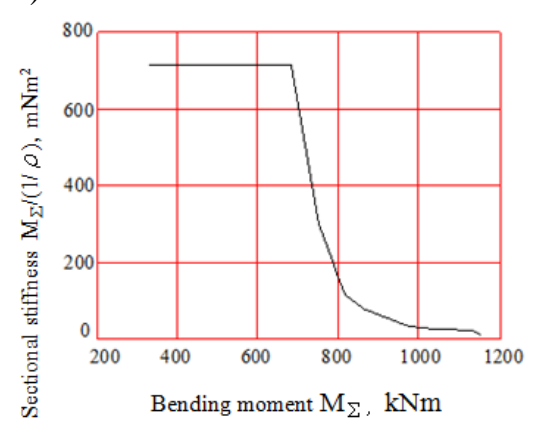

b)

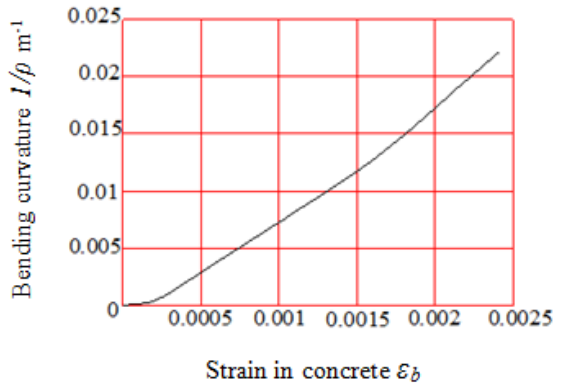

d)

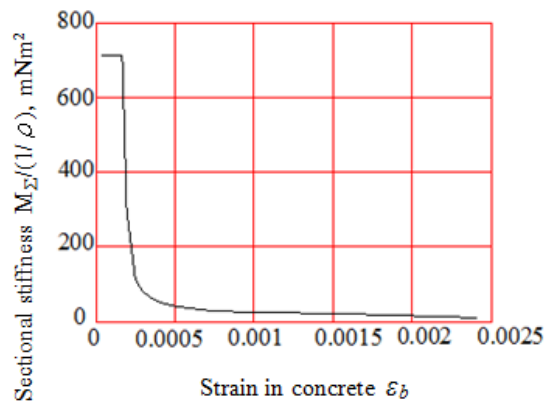

Fig. 6. Diagram of relationship between parameters for the pre-stressed road bridge beam with length 12m: $a-M=f\left(\varepsilon_{b, z=x}\right), b-1 / \rho=f\left(\varepsilon_{b, z=x}\right), c-M_{\Sigma} /(1 / \rho)=f(M), d-M_{\Sigma} /(1 / \rho)=f\left(\varepsilon_{b, z=x}\right)$.

\subsection{Example 2}

Nonlinear deformation analysis of pre-stressed beam system in high-rise building with following parameters: length of beam $7.2 \mathrm{~m}$, elastic modulus $\mathrm{E}_{\mathrm{b}}=34500 \mathrm{MPa}$, pre-stressed reinforcement (class $\mathrm{B}-\mathrm{II}$ ) $\mathrm{E}_{\mathrm{s}}=200000 \mathrm{MPa}$, compression strength of concrete $\mathrm{R}_{\mathrm{b}}=19.5$ $\mathrm{MPa}$, compression strength of reinforcement $\mathrm{R}_{\mathrm{p}}=1055 \mathrm{Mpa}, \sigma_{\mathrm{pn}}=795 \mathrm{Mpa}$

Fig. 7 shows the section of the beam and reinforcement along length of the beam.
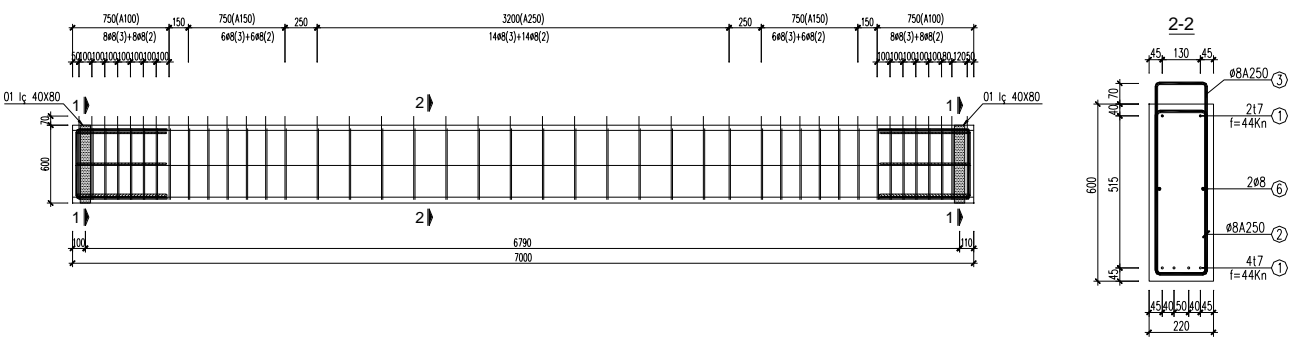

Fig. 7. Diagram of steel distribution along length and at the middle section of the pre-stressed beam using in high-rise building .

The caculation is conducted using programme software MathCad and obtained the results, which illustrated relationships between parameters $M=f_{1}(\rho), M /(1 / \rho)=f_{2}\left(\varepsilon_{b, z=x}\right)$, $M /(1 / \rho)=f_{3}(M)$ and shown in the Figure $8 a, b, c, d$ for the middle section of the pre-stressed road bridge beam with length $7.2 \mathrm{~m}$. 
a)

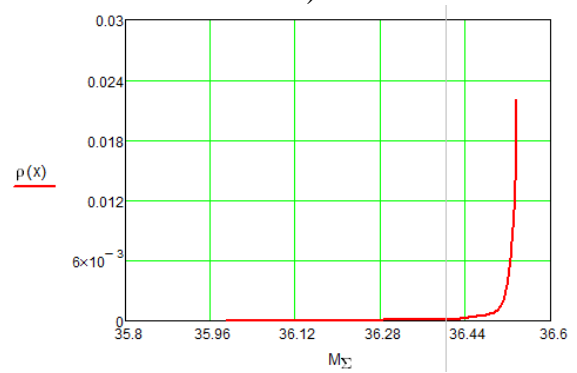

c)

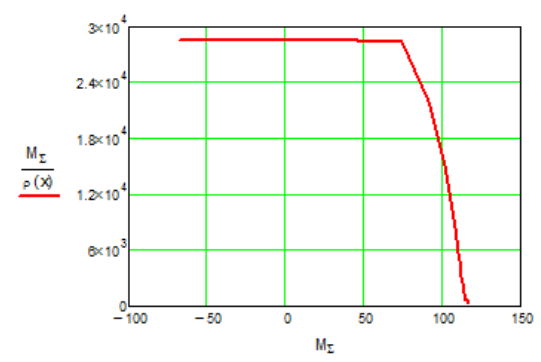

b)

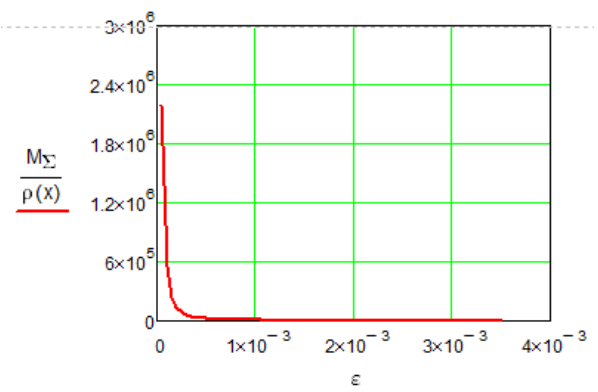

Fig. 8. Diagram of relationship between parameters for the pre-stressed beam using in high - rise building with length 7.2m: $a-\rho=f\left(M_{\Sigma}\right), b-M_{\Sigma} /(1 / \rho)=f\left(\varepsilon_{b, z=x}\right), c-$ $\mathrm{M}_{\Sigma} /(1 / \rho)=\mathrm{f}(\mathrm{M}),-$

\section{Spatial problems}

Spatial problems are conducted with the help of structural analysis software SCAD. During the calculation process, using frame-shell model (Figure 9b) composed of the following elements:

- The rectangular shell element with 3 degrees of freedom at the node, modeling the road bridge decks;

- Frame element with 6 degrees of freedom at the node, modeling for beams.

In the calculation model of road bridge beams system, there is an operation of hard connection to account the height difference of beam centers and the central axis of road bridge decks. Figure 9b shows an example of calculation models of the road bridge span superstructures subjected to two lanes of effective A11 load (live load), illustrating the discrete of decks and beam elements into finite elements, the position of the AK load lane. Selecting the calculation model of the system in the form of frame - shell allows reflecting the distribution and change of section stiffness $M /(1 / \rho)$ in the beam elements depending on the change of bending moment when live load increases gradually.

The load is gradually applied: the initial applied load is static load (self weight) and a part of live load which causes the compressive concrete stress at the middle section the span of the maximum bearing load beam reaching the value $\sigma_{b, z=x}=\sigma_{b 1}$. In the next steps of load applying process, put $\mathrm{AK}=\mathrm{A} 1$ for each time. From the calculation results, draw the diagram of relationship between the displacements of the beams and the AK load being applied with gradually increase of the AK load considering the formation of plastic hinges in the beam system. 

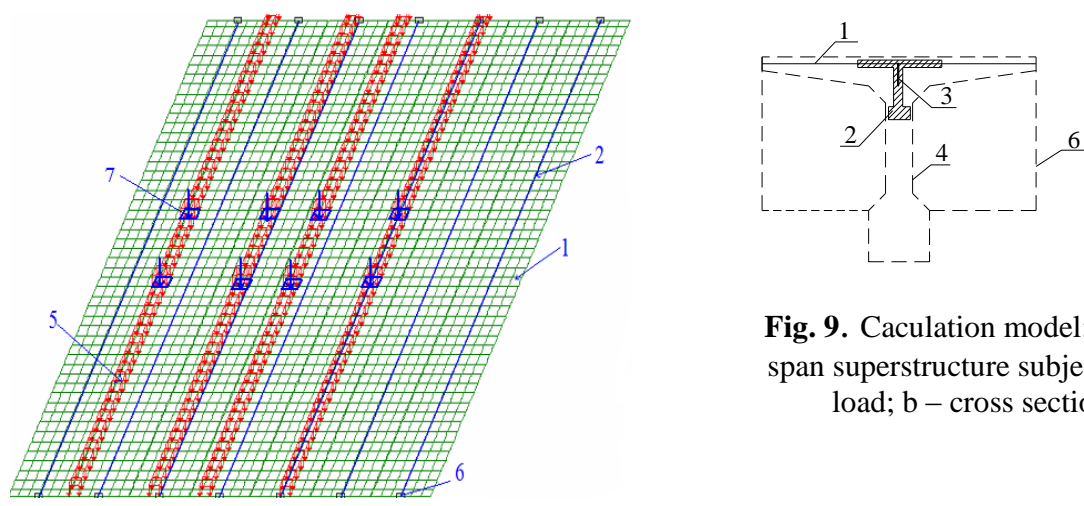

Fig. 9. Caculation model: a - road bridge span superstructure subjected 2 lanes AK load; $b$ - cross section of beam

a)
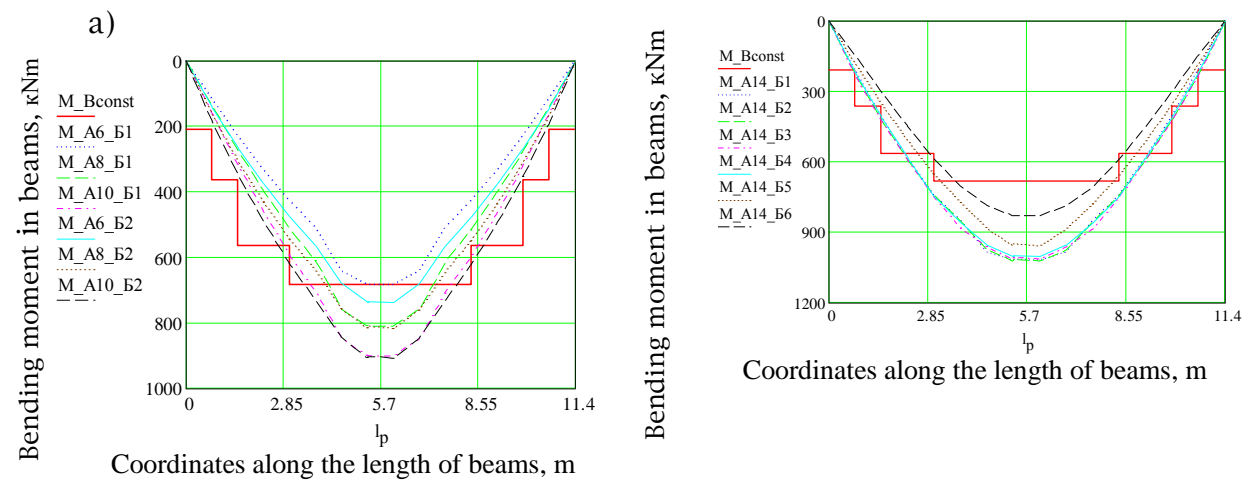

Coordinates along the length of beams, $\mathrm{m}$ b)
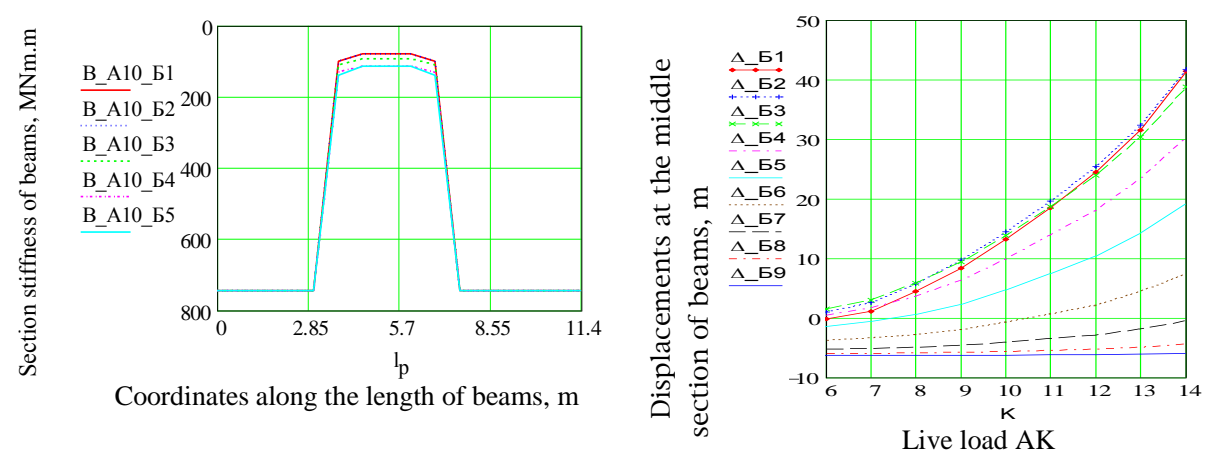

Fig. 10. Results of spatial problem for road bridge span superstructure with length $12 \mathrm{~m}$ : a - Bending moments of the beams; $b$ - Change of section stiffness along the beam; $c$-Displacement at the middle section of beams.

The reach of "limit state including the stress-strain state before fracture" in this problem is recommended by authors according to the following criteria: the displacement at the maximum bearing beam reaches the critical value or the average critical value of the displacement of the entire beam system, the change degree of critical displacement in the maximum bearing beam, the number of plastic hinges formed in the entire beam system.

Figure 10 shows the results of an example of the spatial problem of the road bridge span superstructure composed of 7 beams of length $12 \mathrm{~m}$ : a - diagram of bending moment under the effect of load A8 and A14, diagram of section stiffness distribution $\mathrm{M} /(1 / \rho)$ under the load A8 and A10, the diagram of displacement change of 9 beams. 
According to the calculation results of the road bridge span superstructure, the first plastic hinge is formed at beam 1, 2, 3 under load A13, under load A14, beam B4 became the most bearing load beam, before that the most loaded beams were beam 1, 2 and 3, and at the beginning of the calculation - beam 2; under the effect of load A14 the displacements at the middle section of the beams are: at beam $1-41.4 \mathrm{~mm}$; at $2-41.8 \mathrm{~mm}$; at beam $3-$ $38.8 \mathrm{~mm}$, at beam $4-30.3 \mathrm{~mm}$, the average displacement of the system $-18.7 \mathrm{~mm}$. According to the evaluation criteria of "limit state including the stress-strain state before destroy", the critical load is recommended for the above calculated beam system is A13.

The results of the above example using nonlinear deformation analysis showed that the evaluation criterion of above mentioned "limit state including the stress-strain state before fracture" allows explaining higher load capacity of the beam system compared to evaluation criterion according to the common limit state.

\section{Conclusions}

Nonlinear deformation analysis applying in pre-stressed beam system has established the relationship between internal forces and sectional stiffness, allowing illustration the development of the stress-strain state at any period time of loading process without common caculation procedure. This has important meaning in assessing the bearing load capacity of operating beam system.

The results of nonlinear deformation analysis are applied to the spatial problem of the road bridge span superstructure to change section stiffness when the bending moment in the beam increases, allows seeing the redistribution of the internal force in the whole system. This explains the bearing load capacity of the operating road bridge span superstructure under the condition that they are subjected to a load greater than the design load.

\section{References}

1. Kết cấu bê tông và bê tông cốt thép. Tiêu chuẩn thiết kế TCVN 5574-2012 (2012)

2. The Russian code of rules for designing and construction. Concrete and reinforced concrete structure with precast-prestressed reinforcement. SP 52-101-2003/ FGUP SPP.-2004 - 53s

3. The Russian code of rules for designing and construction. Concrete and reinforced concrete structure with precast-prestressed reinforcement. SP 52-102-2004/ FGUP SPP.-2004 - 53s

4. D.M. Shapiro, A.V. Agarkov, Tran Thi Thuy Van. Spatial non-linear deformational analysis of road bridge multy-beam superstructures. Scientific heralds of Voronezh State University of architecture and civil engineering. Serie of construction and architecture - Voronezh, Russia (2008) p. 29 -37.

5. D.M. Shapiro, Tran Thi Thuy Van. Analysis of road bridge multy-beam superstructures of the standard design in 1957. Scientific heralds of Voronezh State University of architecture and civil engineering - Voronezh, Russia (2007) p. 63 -70.

6. Trần Thị Thúy Vân. Xây dựng quan hệ giữa độ cứng và nội lực nhờ phân tích biến dạng trong dầm hệ nhịp dầm cầu đường bộ. Tạp chí khoa học "Kiến Trúc \& Xây dựng” (2012): p. 54-58.

7. Trần Thị Thúy Vân. Luận án Tiến sĩ kỹ thuật. Phân tích biến dạng phi tuyến không gian hệ dầm bản có sườn ứng dựng trong xây dựng cầu đường bộ, Russia (2009).

8. Trần Trung Hiếu, Trần Thị Thúy Vân. Trạng thái ứng suất biến dạng của dầm cầu đường bộ bê tông cốt thép trong phép phân tích biến dạng phi tuyến. Tạp chí "Giao thông vận tải” (2014) 
9. Trần Thị Thúy Vân. Bài toán biến dạng phi tuyến ứng dụng trong hệ dầm cầu đường bộ ứng suất trước lắp ghép. Hội nghị Khoa học toàn quốc Cơ học Vật rắn lần thứ XIV (2018) 